\title{
FABELSEBAGAI BAHAN PEMBELAJARAN BAHASA DAN SASTRA INDONESIA DI SEKOLAH DASAR
}

\author{
Abdul Azis \\ JBSI FBS UNM Makassar \\ azissa17@yahoo.co.id
}

\begin{abstract}
Abstrak
Pembelajaran sastra cenderung kurang berani menggali teks dalam konteks yang lebih luas. Padahal sangatlah mungkin sebagai media pendidikan dan hiburan, membentuk kepribadian anak, serta menuntun kecerdasan emosi anak. Penelitian ini bertujuan mendeskripsikan cerita rakyat kategori Fabel untuk kepentingan pemilihan bahan ajar Bahasa dan Sastra Indonesia di SD.

Metode yang digunakan dalam penelitian ini adalah metode deskriptif analitik. Data dalam penelitian ini adalah cerita rakyat kategori Fabel. Pengumpulan data dilakukan dengan teknik dokumentasi dari 8 guru SD di 8 kecamatan di Kabupaten Maros Periode Maret-Mei 2014. Teknik analisis meliputi proses pengorganisasian dan pengurutan data tentang Fabel dan pemilihan bahan ajar cerita rakyat ke dalam pola kategori dan satuan uraian.

Hasil analisis data dan temuan menunjukkan bahwa rata-rata penilaian responden untuk cerita rakyat kategori Fabel sebesar 3,763 atau pada kategori layak dijadikan bahan ajar. Bahan ajar yang dapat digunakan dalam pembelajaran cerita rakyat adalah jenis bahan ajar cerita rakyat apa saja. Namun, sebaiknya untuk tingkat SD, bahan ajar cerita rakyat yang digunakan adalah bahan ajar ceita rakyat yang isinya harus sesuai dengan karakteristik, pengalaman, dan kebutuhan siswa.
\end{abstract}

Kata Kunci: Fabel, pemilihan, bahan ajar

\section{A. PENDAHULUAN}

Berpuluh-puluh tahun dari mulai berdirinya bangsa ini, pendidikan kita yang mengedepankan sains dan teknologi, cenderung mengabaikan dan menggeser aspek-aspek humaniora.Bidang-bidang seperti budaya dan seni (termasuk di dalamnya sastra) merupakan bidang-bidang yang cenderung dianak tirikan. Padahal, melalui bidang-bidang inilah kepribadian dan kemanusiaan kita: kepekaan sosial, religi, kehalusan rasa, pembangunan nilai, moral, budi pekerti, dan sejenisnya, terolah dan terasah.

Bukti pengabaian ini misalnya bisa dilihat dari sedikitnya porsi pembelajaran sastra sejak jenjang Sekolah Dasar (SD).Sastra, seperti pada jenjang-jenjang pendidikan di atasnya, merupakan bagian dari mata pelajaran 
Bahasa Indonesia.Akan tetapi, kenyataan di lapangan memperlihatkan mata pelajaran ini lebih didominasi oleh pelajaran tata bahasa. Penelitian A. Chaedar Alwasilah, misalnya, membuktikan bahwa di sekolah-sekolah, sastra hanya diajarkan sebanyak rendah3,6\% saja. Dan, dalam pembelajaran yang hanya rendah3,6\% tersebut, pembelajaran lebih ditekankan pada aspek pengetahuan (kognitif), bukan afektif. Sumber???

Titik berat pembelajaran sastra pada aspek pengetahuan (hafalan) tersebut sudah dikeluhkan banyak pihak sejak tahun 1955-an. Dari mulai H.B Jassin dan Wildan Yatim (Prisma, 1979), Ajip Rosidi (1970), hingga para pengamat dan ahli sastra, serta para pengajar sastra hari ini.Dan, kondisinya belum banyak berubah meski kurikulum telah berkali-kali berganti dengan perumusan tujuan pembelajaran sastra yang lebih ideal.

Berbagai tulisan di media cetak dan berbagai "debat" di forum-forum diskusi pun sebenarnya telah gencar mengangkat tema kegagalan pembelajaran sastra. Tujuannya jelas, yaitu mencari penyebab dan merumuskan solusinya. Banyak pengamat menilai, kegagalan itu disebabkan oleh sempitnya wawasan guru sastra, siswa semakin masa bodoh terhadap mata pelajaran yang berkaitan dengan ajaran moral, guru sastra kurang kreatif, kurikulum yang cenderung memasung dan mengindoktrinasikan berbagai tuntutan, dan pelajaran sastra masih "ikut" pada pelajaran bahasa, sehingga porsi waktu dan muatan materinya kurang mendukung siswa untuk belajar sastra dengan baik. Selain itu juga sebelum melakukan pambelajaran apresiasi sastra guru harus terlebih dahulu memilih bahan ajar dan menentukan metode pembelajaran.

Metode yang digunakan dalam penelitian ini adalah metode deskriptif analitik, yaitu metode penelitian yang bertujuan untuk memerikan suatu fenomena secara analitis, sistematis, faktual, dan teliti. Metode kuantitatif bertujuan untuk mendeskripsikan hasil pemilihan bahan pembelajaran.Data yang diperoleh dari penelitian ini berupa data kualitatif dan data kuantitatif. Metode analisis kualititif sesuai dengan hakikatnya adalah data yang telah terkumpul itu kemudian diseleksi, dikelompokkan, dilakukan pengkajian, interpretasi, dan disimpulkan. Selanjutnya hasil simpulan itu dideskripsikan. 
Data dalam penelitian ini berupa cerita rakyat kategori Fabel dalam masyarakat. Pengambilan data dari cerita rakyat yang telah dipublikasikan ini didasarkan pertimbangan bahwa masalah yang muncul pada terbitan masyarakat tersebut lebih bervariasi. Pengambilan data ini juga disesuaikan dengan kemampuan tenaga, waktu, dan biaya yang ada.Data partisipan berupa guru yang mengajar Bahasa dan Sastra Indonesia di kelas kelas V dan VI Sekolah Dasar di Kabupaten Maros, Provinsi Sulawesi Selatan. Alasan pengambilan data di kelas V dan VI karena materi pembelajaran sastra terdapat di kelas tersebut.

Sumber data data dalam penelitian ini adalah purposive sampling yang merupakan cara pengambilan sumber data berdasarkan karakteristik tertentu yang dimiliki sumber data sesuai dengan tujuan penelitian. Penentuan besar dan banyaknya sumber data bergantung kepada peneliti dengan berdasarkan pada berbagai pertimbangan dan tujuan tertentu. Seperti halnya data, sumber data penelitian dibagi ke dalam dua bagian, yaitu bahan pemilihan karya sastra cerita rakyat dan sumber data partisipan (guru). Sumber data partisipan adalah guru yang mengajar Bahasa dan Sastra Indonesia di kelas V dan VI Sekolah Dasar di Kabupaten Maros, Provinsi Sulawesi Selatan.

Pengumpulan data dilakukan dengan teknik dokumentasi dan observasi dengan menelusuri cerita rakyat kategori Fabelyang telah dipublikasi lembaga resmi pemerintahan daerah/provinsi; memilih dan menentukan teks yang memenuhi persyaratan untuk diteliti; menganalisis cerita rakyat dari aspek isi untuk mengungkapkan karakteristik yang mendukung cerita rakyat sebagai alternatif bahan ajar; mendeskripsikan data yang telah ditabulasikan; dan membuat laporan penelitian.

Data cerita rakyat setelah dianalisis dengan menggunakan pedoman analisis kemudian dideskripsikan. Data yang dideskripsikan adalah aspek penyusunan pemilihan bahan ajar dari cerita rakyat kategori Fabelyang telah dipublikasi lembaga resmi pemerintahan daerah/provinsi.

Berdasarkan langkah tersebut maka semua data hasil pemilihan cerita rakyat dikelompokkan berdasarkan aspek pemilihan cerita rakyat sebagai bahan ajar kemudian ditabulasikan. Selanjutnya data tersebut dimasukkan ke dalam tabel dan kemudian dihitung menurut persentase. Persentase itu untuk memberikan 
gambaran yang lebih jelas mengenai kedudukan suatu bagian dalam keseluruhan, yaitu yang berhubungan dengan aspek pemilihan cerita rakyat sebagai bahan ajardan aspek prinsip penyusunan bahan ajar. Pada dasarnya pengolahan data penelitian ini menggunakan pendekatan kualitatif dalam bentuk persentase.Selanjutnya hasil simpulan itu dideskripsikan. Pada dasarnya pengolahan data penelitian ini menggunakan pendekatan kuantitatif dalam bentuk persentase

Penelitian ini menggunakan instrumen, yaitu pedoman pemilihan cerita rakyat menjadi bahan ajar dan tes. Pedoman analisis digunakan untuk mendeskripsikan pemilihan cerita rakyat menjadi bahan ajar yaitu untuk mengetahui aspek tingkatkelayakan cerita rakyat sebagai bahan ajar.

\section{B. PEMBAHASAN}

\section{Pemilihan Cerita Rakyat sebagai Bahan Ajar}

Menurut Haryati (2007:9), bahan ajar atau materi pembelajaran secara garis besar terdiri dari pengetahuan, keterampilan, dan sikap yang harus dipelajari siswa dalam rangka mencapai standar kompetensi yang telah ditentukan. Secara terperinci, jenis-jenis materi pembelajaran terdiri dari pengetahuan (fakta, konsep, prinsip, prosedur) keterampilan, sikap atau nilai. Menurut Azis (2010: 88), masalah bahan ajar merupakan penting yang sering dihadapi guru ketika memilih atau menentukan materi karena dalam kurikulum (silabus) hanya dituliskan secara garis besar dalarn bentuk materi pokok

Ada 3 ciriyang menandai sastra anak itu berbeda dengan sastra orang dewasa, diantaranya: Unsur pantangan, penyajian dengan gaya secara langsung, fungsi terapan. Sastra anak memiliki fungsi sebagai media pendidikan dan hiburan, membentuk kepribadian anak, serta menuntun kecerdasan emosi anak (sumber).

Pengertian dari kata apresiasi, yaitu kesadaran kita terhadap nilai-nilai seni dan budaya (sastra anak) serta penilaian atau penghargaan kita terhadap sesuatu (sastra anak).Jadi karya sastra anak merupakan penghargaan terhadap karya sastra 
yang dibuat oleh anak berdasarkan pengalaman, imajinasi, dan penglihatan anak sehingga menambah motivasi anak untuk meningkatkan karya sastranya.

Tujuan pembelajaran sastra pada tiap-tiap dan tingkatan sekolah pada dasarnya sama, hanya saja ada perbedaan tekanan sehubungan dengan jenis dan tingkatan sekolah, yaitu menumbuhkan keterampilan berbahasa. Rahmanto (2008:16) mengatakan bahwa pengajaran sastra dapat membantu pendidikan secara utuh apabila cakupannya meliputi empat manfaat, yaitu membantu keterampilan berbahasa, meningkatkan pengetahuan budaya, mengembangkan cipta dan rasa, dan menunjang pembentukan watak.

Pada dasarnya dalam memilih bahan pembelajaran, penentuan jenis, dan kandungan materi sepenuhnya terletak di tangan guru. Namun, demikian, ada beberapa hal yang perlu diperhatikan sebagai dasar pegangan untuk memilih objek bahan pelajaran yang berkaitan dengan pembinaan apresiasi siswa. Prinsip dasar dalam pernilihan bahan ajar harus sesuai dengan kemampuan siswa pada suatu tahapan pengajaran tertentu. Kemampuan siswa berkembang sesuai dengan tahapan perkembangan jiwanya.

Apabila kita memperhatikan degan seksama GBPP/silabus mata pelajaran Bahasa Indonesia terutama di SD, maka dapat disimpulkan bahwa bahan ajar yang paling sering dan banyak harus dipersiapkan adalah wacana atau cerita rakyat dengan berbagai tema. Wacana dengan tema tertentu berfungsi juga sebagai wadah kegiatan berbahasa lainnya. Karena dalam wacana terdapat bahan kajian untuk pembelajaran kebahasaan, pemahaman, dan penggunaan tertentu. Termasuk dalam hal ini kegiatan apresiasi sastra pun dapat berfungsi sebagai wadah kegiatan berbahasa lainnya. Oleh karena itu, sangat dianjurkan sesering mungkin menggunakan karya sastra sebagai wacana bahan pembelajaran.

Menurut Tarigan (2005:60), paling sedikit ada dua hal penting yang harus diketahui oleh guru Bahasa dan Sastra Indonesia mengenai wacana sebagai bahan pembelajaran. Pertama, guru harus mengetahui berbagai kriteria yang digunakan untuk menentukan suatu wacana baik atau tidak baik sebagai bahan pembelajaran. Kedua, guru harus dapat mengembangkan, menyusun, memilih, atau menyadur suatu wacana sebagai bahan pembelajaran. 
Menurut Tarigan (2005: 61), suatu wacana berbentuk cerita rakyat dianggap layak sebagai bahan ajar apabila cerita rakyat tersebut 1) memenuhi kriteria dalam GBPP/silabus, 2) isi wacana dapat menjadi contoh yang dapat diteladani, 3) dapat memantapkan nilai dan norma yang dianut oleh cerita rakyat sesuai dengan usia, minat, lingkungan, dan kebutuhan, 4) tidak menyinggung persoalan SARA, dan 5) struktur wacana harus baik.

\section{Kriteria Pemilihan Bahan Ajar}

Pelaksanaan pembelajaran apresiasi sastra anak di sekolah dasar dapat dimulai dari kegiatan pra-KBM (Kegiatan Belajar Mengajar) hingga KBM di kelas. Kegiatan pra-KBM dapat dilakukan dengan memberi salinan atau kopi teks sastra, diberi tugas membaca, menghafalkan, meringkas atau mencatat dan menemukan arti kata-kata sukar yang terdapat dalam teks sastra. KBM di kelas dapat dilakukan dengan memberi tugas membaca sajak, membaca cerita, berdeklamasi atau mendongeng di depan kelas, Setelah itu baru diadakan tanya jawab, menuliskan pendapat, dan berdiskusi bersama merumuskan isi, tema, dan amanat.

Sebelum melaksanakan pemilihan bahan ajar, terlebih dahulu perlu diketahui kriteria pemilihan bahan ajar. Kriteria pokok pemilihan bahan ajar atau materi pembelajaran adalah standar kompetensi dan kompetensi dasar. Hal ini berarti bahwa materi pembelajaran yang dipilih untuk diajarkan pada siswa hendaknya berisi materi atau bahan ajar yang benar-benar menunjang tercapainya standar kompetensi dan kompetensi dasar. Dengan kata lain, pemilihan bahan ajar haruslah mengacu atau merujuk pada standar kompetensi. Menurut Depdiknas (2006:195), secara garis besar langkah-langkah pemilihan bahan ajar meliputi halhal berikut:

1. Mengidentifikasi aspek-aspek yang terdapat dalam standar kompetensi dan kompetensi dasar yang menjadi acuan atau rujukan pemilihan bahan ajar.

2. Mengidentifikasi jenis-jenis materi bahan ajar.

3. Memilih bahan ajar yang sesuai atau relevan dengan standar kompetensi dan kompetensi dasar yang telah teridentifikasi tadi. 
4. Memilih sumber bahan ajar.

Menurut Depdiknas (2006:196), cara paling mudah untuk menentukan jenis materi pembelajaran yang akan diajarkan adalah dengan mengajukan pertanyaaan tentang kompetensi dasar yang harus dikuasai siswa.

\section{Pemilihan Bahan Ajar Cerita Rakyat dalam Pembelajaran}

Bahan ajar dapat diperoleh dari buku-buku bacaan sastra anak di perpustakaan sekolah, perpustakaan pemerintah daerah, took buku ataupun buku pelajaran sekolah yang sudah tersedia. Namun apabila belum tersedia dalam buku pelajaran sekolah, seorang guru harus mencarinya ke tempat-tempat tersebut.Bahan ajar harus sesuai dengan anak didik sehingga pertimbangan usia anak didik menjadi pilihan utama. Keberagaman tema, keberagaman pengarang, dan bobot atau mutu karya sastra yang akan dijadikan bahan ajar juga menjadi pertimbangan yang matang. Menentukan metode harus disesuaikan dengan kemampuan guru dan kebutuhan serta kesesuaian dengan keadaan siswa. Menuliskan persiapan mengajar harian merupakan salah satu bentuk keprofesionalan seorang guru. Penulisan PMH itu juga menunjukkan bahwa guru siap secara lahir batin hendak menyampaikan pembelajaran apresiasi sastra anak di sekolah dasar.

Menurut Azis (2011: 12), pada dasarnya dalam memilih bahan pembelajaran, penentuan jenis, dan kandungan materi sepenuhnya terletak di tangan guru. Namun, demikian, ada beberapa hal yang perlu diperhatikan sebagai dasar pegangan untuk memilih objek bahan pelajaran yang berkaitan dengan pembinaan apresiasi siswa. Prinsip dasar dalam pernilihan bahan ajar harus sesuai dengan kemampuan siswa pada suatu tahapan pengajaran tertentu. Kemampuan siswa berkembang sesuai dengan tahapan perkembangan jiwanya. Oleh karena itu, karya sastra yang disajikan hendaknya diklasifikasikan berdasarkan derajat kesukarannya di samping kriteria-kriteria lainnya. Tanpa adanya kesesuaian antara siswa dengan bahan yang diajarkan, pelajaran yang disampaikan akan gagal.

Menurut Depdiknas (2006:193), bahan ajar atau materi pembelajaran (instructional materials) merupakan salah satu komponen sistem pembelajaran 
yang memegang peranan penting dalam membantu siswa mencapai standar kompetensi dan kompetensi dasar. Secara garis besar, bahan ajar atau materi pembelajaran berisikan pengetahuan, keterampilan, dan sikap atau nilai yang harus dipelajari siswa.

Menurut Depdiknas (2006:195) dan Haryati (2007:7), ada beberapa prinsip dalam penyusunan bahan ajar atau materi pembelajaran antara lain adalah sebagai berikut.

1. Prinsip relevansi, yaitu adanya kesesuaian antara materi pokok dengan kompetensi dasar yang ingin dicapai.

2. Prinsip konsistensi, yaitu adanya keajegan antara materi pokok dengan kompetensi dasar dan standar kompetensi.

3. Prinsip kecukupan (adekuasi), yaitu materi yang diajarkan hendaknya cukup memadai dalam membantu siswa menguasai kompetensi dasar yang diajarkan.

Pembelajaran apresiasi sastra anak di sekolah dasar meliputi tiga tahapan yang harus dilalui seorang guru, yaitu :

1. Persiapan pembelajaran,

2. Pelaksanaan pembelajaran, dan

3. Evaluasi pembelajaran.

Tahap persiapan pembelajaran apresiasi sastra anak di sekolah dasar bagi seorang guru dapat menyangkut dengan dirinya, yaitu

1. Persiapan fisik, dan

2. Persiapan mental.

Fisik seorang guru harus sehat jasmaninya, tidak sakit-sakitan.Mentalnya pun harus sehat jiwanya, tidak sakit ingatan.

Sementara itu, hal-hal teknis yang perlu dipersiapkan adalah:

1. Memilih bahan ajar,

2. Menentukan metode pembelajaran, dan

3. Menuliskan persiapan mengajar harian.

Bahan ajar harus sesuai dengan anak didik sehingga pertimbangan usia anak didik menjadi pilihan utama. Keberagaman tema, keberagaman pengarang, dan bobot atau mutu karya sastra yang akan dijadikan bahan ajar juga menjadi 
pertimbangan yang matang. Menentukan metode harus disesuaikan dengan kemampuan guru dan kebutuhan serta kesesuaian dengan keadaan siswa.Menuliskan persiapan mengajar harian merupakan salah satu bentuk keprofesionalan seorang guru.Penulisan PMH itu juga menunjukkan bahwa guru siap secara lahir batin hendak menyampaikan pembelajaran apresiasi sastra anak di sekolah dasar.

Pelaksanaan pembelajaran apresiasi sastra anak di sekolah dasar dapat dimulai dari kegiatan pra-KBM (Kegiatan Belajar Mengajar) hingga KBM di kelas.Kegiatan pra-KBM dapat dilakukan dengan memberi salinan atau kopi teks sastra, diberi tugas membaca, menghafalkan, meringkas atau mencatat dan menemukan arti kata-kata sukar yang terdapat dalam teks sastra. KBM di kelas dapat dilakukan dengan memberi tugas membaca sajak, membaca cerita, berdeklamasi atau mendongeng di depan kelas, Setelah itu baru diadakan tanya jawab, menuliskan pendapat, dan berdiskusi bersama merumuskan isi, tema, dan amanat (Santosa, dkk., 2008).

Sebelum melaksanakan pemilihan bahan ajar, terlebih dahulu perlu diketahui kriteria pemilihan bahan ajar. Kriteria pokok pemilihan bahan ajar atau materi pembelajaran adalah standar kompetensi dan kompetensi dasar. Hal ini berarti bahwa materi pembelajaran yang dipilih untuk diajarkan pada siswa hendaknya berisi materi atau bahan ajar yang benar-benar menunjang tercapainya standar kompetensi dan kompetensi dasar. Dengan kata lain, pemilihan bahan ajar haruslah mengacu atau merujuk pada standar kompetensi. Menurut Depdiknas (2006:195), secara garis besar langkah-langkah pemilihan bahan ajar meliputi halhal berikut:

1. Mengidentifikasi aspek-aspek yang terdapat dalam standar kompetensi dan kompetensi dasar yang menjadi acuan atau rujukan pemilihan bahan ajar.

2. Mengidentifikasi jenis-jenis materi bahan ajar.

3. Memilih bahan ajar yang sesuai atau relevan dengan standar kompetensi dan kompetensi dasar yang telah teridentifikasi tadi.

4. Memilih sumber bahan ajar. 
Menurut Depdiknas (2006:196), cara paling mudah untuk menentukan jenis materi pembelajaran yang akan diajarkan adalah dengan mengajukan pertanyaaan tentang kompetensi dasar yang harus dikuasai siswa.

Agar dapat memilih bahan pengajaran sastra dengan tepat, beberapa aspek perlu dipertimbangkan. Menurut Rahmanto (2008:27), ada tiga aspek penting yang tidak boleh dilupakan jika ingin memilih bahan pengajaran sastra, yaitu bahasa, psikologi, dan latar belakang budaya.

\section{Analisis Data dan Pembahasan Hasil Penelitian}

Temuan dan analisis pemilihan cerita rakyat kategori Fabel menjadi bahan ajar dibagi menjadi sepuluh bagian. Keseluruhan cerita rakyat kategoriFabel yang diteliti dan dianalisis kesesuaian isinya dengan bahan ajar berjumlah 5 buah cerita rakyat kategori Fabel yang diteliti, masing-masing berjudul Kisah Pelanduk dengan Macan, La Dana dan Kerbaunya, Lapung Dare’ Siagang Lapung KuraKura, Pung Buaja Na Pung Kura-Kura, Ceritera Musang Berjanggut. Temuan dan analisis kesesuaian isi cerita rakyat kategori Fabel dengan bahan ajar dibagi menjadi sepuluh bagian.

Pembahasan penilaian respondenyang berkaitan pemilihan cerita rakyatkategori Fabelsebagai bahan ajar pembelajaran Bahasa dan Sastra Indonesia di Sekolah Dasar digambarkan pada tabel 1, grafik 1, dan grafik 2.Temuan dan analisis yang diperoleh dari responden lebih jelasnya dapat dilihat pada tabel 1 .

Tabel 1.

Rekapitulasi Rata-rata Penilaian Kesesuaian Isi Cerita Rakyat Kategori Fabeldengan Bahan Ajar

\begin{tabular}{|c|c|c|c|c|c|c|c|c|}
\hline \multirow{2}{*}{ No. } & \multirow{2}{*}{ Aspek Pemilihan } & \multicolumn{5}{|c|}{ Cerita Rakyat } & \multirow{2}{*}{$\begin{array}{c}\text { Jumla } \\
\text { h }\end{array}$} & \multirow{2}{*}{$\begin{array}{l}\text { Rata } \\
\text {-rata }\end{array}$} \\
\hline & & F.1 & F.2 & F.3 & F.4 & F.5 & & \\
\hline 1. & $\begin{array}{l}\text { Bahasa cerita rakyat sesuai } \\
\text { tingkat kemampuan } \\
\text { berbahasa siswa }\end{array}$ & 3 & 3.75 & 3.875 & 3.375 & 3.875 & 28.6 & 3.575 \\
\hline 2. & $\begin{array}{l}\text { Situasi cerita rakyat sesuai } \\
\text { tingkat kemampuan }\end{array}$ & 3.75 & 3 & 3.625 & 3.75 & 3.75 & 28.6 & 3.575 \\
\hline
\end{tabular}




\begin{tabular}{|c|c|c|c|c|c|c|c|c|}
\hline & berbahasa siswa & & & & & & & \\
\hline 3. & $\begin{array}{l}\text { Isi cerita rakyat sesuai } \\
\text { tingkat kemampuan } \\
\text { berbahasa siswa }\end{array}$ & 4.875 & 3.625 & 4 & 4.125 & 3.75 & 32.6 & 4.075 \\
\hline 4. & $\begin{array}{l}\text { Ungkapan/referensi cerita } \\
\text { rakyat sesuai tingkat } \\
\text { kemampuan berbahasa } \\
\text { siswa }\end{array}$ & 3.625 & 4.25 & 4.25 & 2.875 & 4.5 & 31.2 & 3.9 \\
\hline 5. & $\begin{array}{l}\text { Isi cerita rakyat sesuai } \\
\text { tingkat perkembangan } \\
\text { kematangan psikologis } \\
\text { siswa }\end{array}$ & 4.375 & 3.75 & 3.625 & 3.75 & 3.625 & 30.6 & 3.825 \\
\hline 6. & $\begin{array}{l}\text { Latar belakang budaya cerita } \\
\text { rakyat sesuai kondisi } \\
\text { lingkungan belajar siswa }\end{array}$ & 3.75 & 3.375 & 4 & 3.625 & 3.625 & 29.4 & 3.675 \\
\hline 7. & $\begin{array}{l}\text { Cerita rakyat membantu } \\
\text { keterampilan berbahasa } \\
\text { siswa }\end{array}$ & 4.375 & 3.5 & 3.875 & 3.75 & 3.375 & 30.2 & 3.775 \\
\hline 8. & $\begin{array}{l}\text { Cerita rakyat meningkatkan } \\
\text { pengetahuan budaya siswa }\end{array}$ & 3.5 & 4 & 3.75 & 2.875 & 4.25 & 29.4 & 3.675 \\
\hline 9. & $\begin{array}{l}\text { Cerita rakyat } \\
\text { mengembangkan cipta dan } \\
\text { rasa siswa }\end{array}$ & 4.125 & 3 & 4 & 3.75 & 3.875 & 30 & 3.75 \\
\hline 10. & $\begin{array}{l}\text { Cerita rakyat menunjang } \\
\text { pembentukan watak siswa }\end{array}$ & 3.875 & 3.625 & 4.125 & 3.75 & 3.625 & 30.4 & 3.8 \\
\hline & Jumlah & 39.25 & $\begin{array}{c}35.87 \\
5\end{array}$ & $\begin{array}{c}39.12 \\
5\end{array}$ & $\begin{array}{c}35.62 \\
5\end{array}$ & 38.25 & 301 & 37.625 \\
\hline & Rata-rata & 3.925 & 3.588 & 3.913 & 3.563 & 3.825 & 30.1 & 3.763 \\
\hline
\end{tabular}

Keterangan: $(\mathrm{F}=$ Fabel $)$

Secara grafik, rata-rata penilaian responden yang berkaitan pemilihan cerita rakyatsebagai bahan ajar pembelajaran Bahasa dan Sastra Indonesia di Sekolah Dasar aspek isi cerita rakyat kategori Fabel jelasnya dapat dilihat pada grafik 1 . 


\section{Grafik 1.}

\section{Rekapitulasi Jawaban Kesesuaian Aspek Isi Cerita Rakyat Kategori Fabeldengan Bahan Ajar}

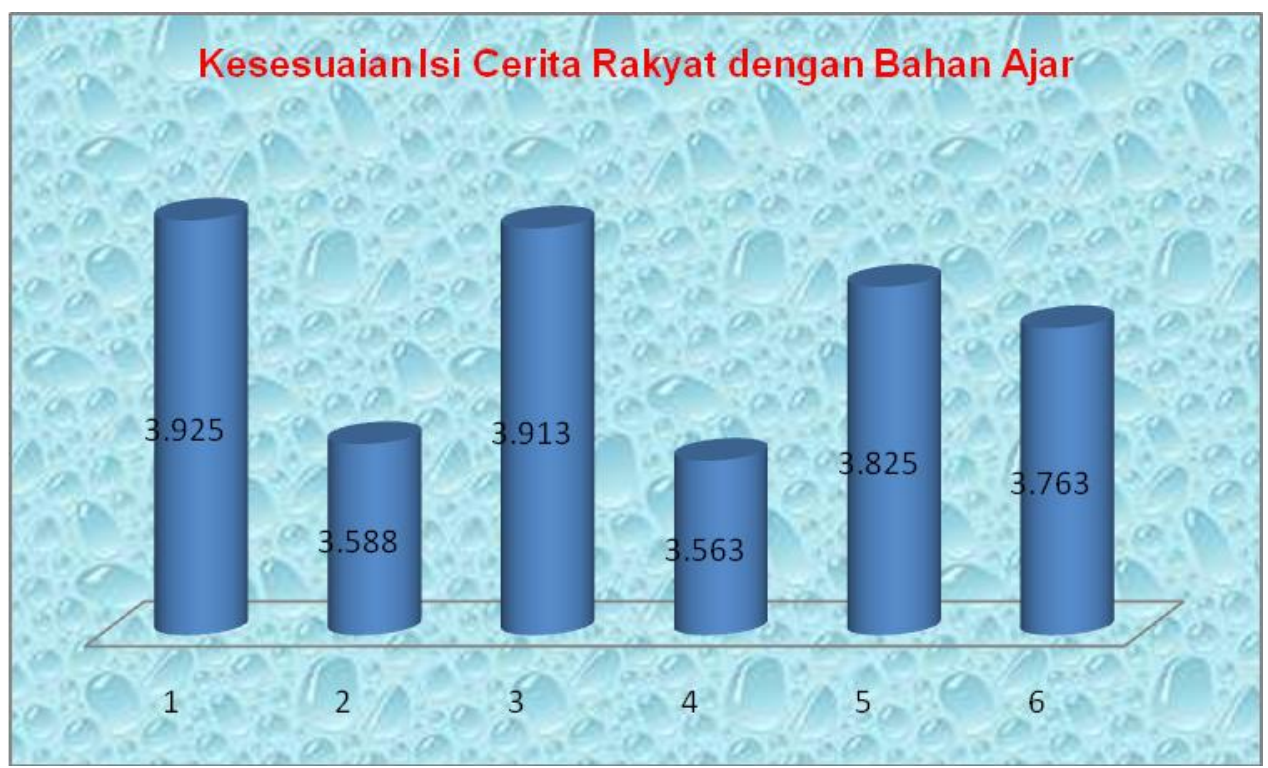

Secara umum,rata-rata penilaian respondenyang berkaitan pemilihan cerita rakyatkategori Fabelsebagai bahan ajar pembelajaran Bahasa dan Sastra Indonesia di Sekolah Dasar adalah 3,80atau pada kategori layak dijadikan bahan ajar.

Secara grafik, rata-rata penilaian responden yang berkaitan pemilihan cerita rakyatsebagai bahan ajar pembelajaran Bahasa dan Sastra Indonesia di Sekolah Dasar setiap aspek isi cerita rakyat kategori Fabel jelasnya dapat dilihat pada grafik 2.

\section{Grafik 2.}

\section{Rekapitulasi Rata-rata Penilaian Kesesuaian Aspek Isi Cerita Rakyat} Kategori Fabeldengan Bahan Ajar 


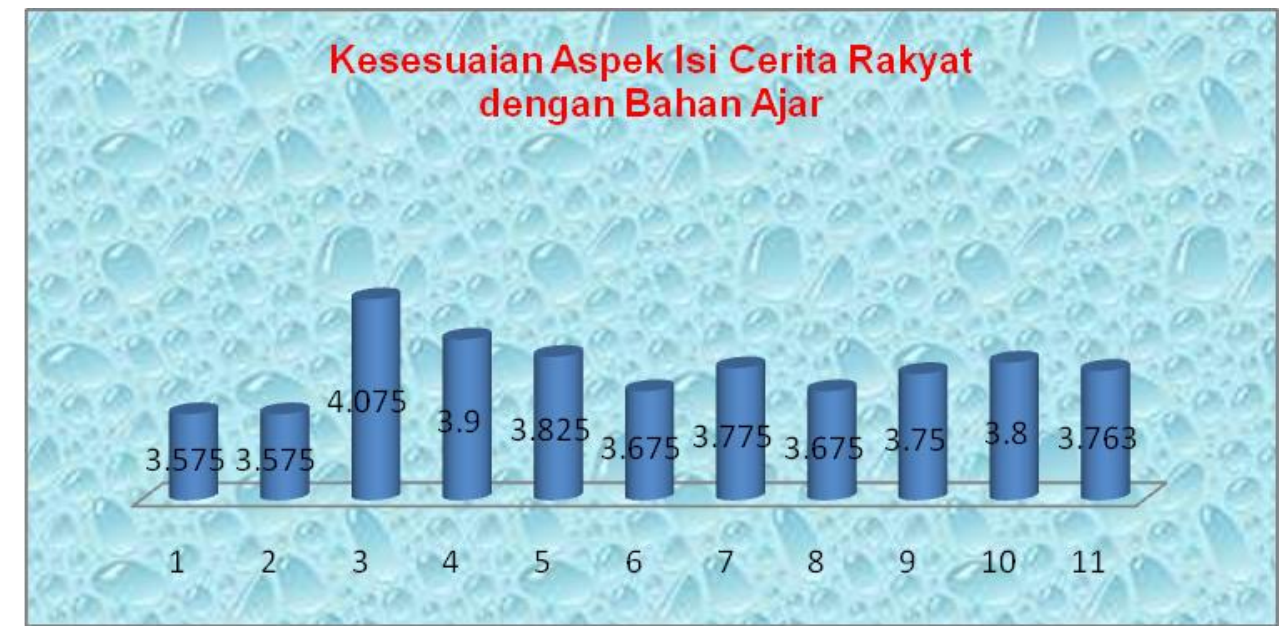

Berdasarkan tabel 1 dan grafik 2 tersebut, maka diketahui penilaian responden tentang pemilihan cerita rakyat sebagai bahan ajarpembelajaran Bahasa dan Sastra Indonesia di Sekolah Dasar aspek isi cerita rakyat kategori Fabel. Temuan dan analisis yang berkaitan dengan aspek pemilihan cerita rakyat sebagai bahan ajar pembelajaran Bahasa dan Sastra Indonesia di Sekolah Dasar dibagi menjadi sepuluh bagian. Pertama, aspek berkaitan dengan bahasa cerita rakyat sesuai tingkat kemampuan berbahasa siswa, hasilnya adalah 3,94 atau pada kategori layak dijadikan bahan ajar. Kedua, aspek situasi cerita rakyat sesuai tingkat kemampuan berbahasa siswa, hasilnya adalah 3,8 atau pada kategori layak dijadikan bahan ajar. Ketiga, aspek berkaitan dengan isi cerita rakyat sesuai tingkat kemampuan berbahasa sisswa, hasilnya adalah 3,87 atau pada kategori layak dijadikan bahan ajar. Keempat, aspek ungkapan/referensi cerita rakyat sesuai tingkat kemampuan berbahasa siswa, hasilnya adalah 3,59 atau pada kategori layak dijadikan bahan ajar. Kelima, aspek berkaitan dengan isi cerita rakyat sesuai tingkat perkembangan kematangan psikologis siswa, hasilnya adalah 3,83 atau pada kategori layak dijadikan bahan ajar. Keenam, aspek latar belakang budaya cerita rakyat sesuai kondisi lingkungan belajar siswa, hasilnya adalah 3,72 atau pada kategori layak dijadikan bahan ajar. Ketujuh, aspekcerita rakyat membantu membantu keterampilan berbahasa siswa, hasilnya adalah 3,87 atau pada kategori layak dijadikan bahan ajar. Kedelapan, aspekcerita rakyat meningkatkan pengetahuan budaya siswa, hasil analisisnya adalah 3,73 atau 
pada kategori layak dijadikan bahan ajar. Kesembilan, aspekcerita rakyat mengembangkan cipta dan rasa siswa, hasilnya adalah 3,78 atau pada kategori layak dijadikan bahan ajar. Kesepuluh, aspekcerita rakyat menunjang pembentukan watak siswa, hasilnya adalah 3,84 atau pada kategori layak dijadikan bahan ajar. Secara umum rata-rata penilaian responden kesesuaian aspek isi cerita rakyatkategori Fabeldengan bahan ajar pembelajaran Bahasa dan Sastra Indonesia di Sekolah Dasar adalah 3,763atau pada kategori layak dijadikan bahan ajar.

\section{PENUTUP}

Berdasarkan pendeskripsian analisis data, pembahasan hasil penelitian, dan temuan yang telah diuraikan sebelumnya, hasil penelitian ini dapat disimpulkan bahwa aspek pemilihan cerita rakyat sebagai bahan ajar dibagi menjadi sepuluh subaspek, yaitu subaspek berkaitan dengan bahasa cerita rakyat sesuai tingkat kemampuan berbahasa siswa, subaspek situasi cerita rakyat sesuai tingkat kemampuan berbahasa siswa, subaspek berkaitan dengan isi cerita rakyat sesuai tingkat kemampuan berbahasa sisswa, subaspek ungkapan/referensi cerita rakyat sesuai tingkat kemampuan berbahasa siswa, subaspek berkaitan dengan isi cerita rakyat sesuai tingkat perkembangan kematangan psikologis siswa, subaspek latar belakang budaya cerita rakyat sesuai kondisi lingkungan belajar siswa, subaspekcerita rakyat membantu membantu keterampilan berbahasa siswa, subaspekcerita rakyat meningkatkan pengetahuan budaya siswa, subaspekcerita rakyat mengembangkan cipta dan rasa siswa, dan subaspekcerita rakyat menunjang pembentukan watak siswa. Rata-rata penilaian responden kesesuaian aspek pemilihan cerita rakyat dengan bahan ajar adalah 3,848(layak dijadikan bahan ajar).

Jenis materi bahan ajar cerita rakyat perlu diidentifikasi atau ditentukan dengan tepat karena setiap jenis materi bahan ajar cerita rakyat memerlukan strategi, media, dan cara mengevaluasi yang berbeda-beda. Cakupan atau ruang lingkup serta kedalaman materi bahan ajar cerpen perlu diperhatikan agar tidak kurang dan tidak lebih. Urutan (sequence) perlu diperhatikan agar bahan ajar cerita rakyat menjadi runtut. Perlakuan (cara mengajarkan/menyampaikan dan 
mempelajari) perlu dipilih setepat-tepatnya agar tidak salah mengajarkan atau mempelajarinya (misalnya perlu kejelasan apakah suatu materi harus dihapalkan, dipahami, atau diaplikasikan).

\section{DAFTAR PUSTAKA}

Azis, Abdul. 2010. Cerita Pendek pada Surat Kabar sebagai Bahan Ajar.Laporan Hasil Penelitian. Bandung: LPM UPI.

2011. Pemilihan Cerita Pendek dalam Surat Kabar sebagai Bahan Ajar dan Hasil Pembelajaran Bahasa dan Sastra Indonesiadi Sekolah Menengah Atas dalam Jurnal Metasastra. Bandung: Balai Bahasa Bandung.

Depdiknas. 2006. Kurikulum 2006. Standar Kompetensi Pelajaran Bahasa Indonesia SD dan MI. Jakarta: Departeman Pendidikan Nasional.

Haryati, Mimin. 2007. Model dan Teknik Penilaian pada Tingkat Satuan Pendidikan. Jakarta: Gaung Persada Press.

Rahmanto, B. 2008. Metode Pengajaran Sastra. Yogyakarta: Kanisius.

Santosa, Puji, dkk. 2008. Materi dan Pembelajaran Bahasa IndonesiaSD.Jakarta:Universitas Terbuka.

Sudaryanto. 2008. Metode dan Aneka Teknik Analisis Bahasa. Yogyakarta: Duta Wacana University Press. 2002. Dasar-Dasar Teori Sastra. Surakarta: Widya Duta.

Suyitno. 2005. Teknik Pengajaran Apresiaasi Sastra dan Kemampuan Bahasa Yogyakarta: PT Hanindita.

Tarigan, H.G. 2005. Prinsip-Prinsip Dasar Sastra. Bandung: Angkasa.

Rusyana, Yus. 1999. "Sastra Klasik Milik Bangsa Indonesia”. Jakarta: Dimuat dalam Cerita Rakyat Media Indonesia (30 Desember 1999).

2002. "Naskah Nusantara Dalam Pendidikan Kesastraan Di Indonesia". Makalah Seminar Internasional Bahasa dan Sastra Indonesia dengan Dewan Bahasa dan Pustaka, Malaysia. Bogor. 